\title{
ISOENZYME ANALYSIS OF FIVE ENDEMIC AND ONE WIDESPREAD KNIPHOFIA SPECIES (ASPHODELACEAE) OF ETHIOPIA
}

\author{
Tilahun Teklehaymanot ${ }^{1}$, Endashaw Bekele ${ }^{2}$, Sebsebe Demissew ${ }^{2}$ and Inger Nordal ${ }^{3}$ \\ ${ }^{1}$ Institute of Pathobiology, Addis Ababa University, PO Box 56478, \\ Addis Ababa, Ethiopia. E-mail: tilahunmt@yahoo.com \\ ${ }^{2}$ Faculty of Science, Addis Ababa University, PO Box 3434, Addis Ababa, Ethiopia \\ 3Inger Nordal, University of Oslo, PO Box 1066 Blindern, N-0316 Oslo, Norway
}

\begin{abstract}
There are seven species of genus Kniphofia in Ethiopian flora. K. foliosa, K. hildebrandtii, K. insignis, K. isoetifolia, and K. schimperi are endemic. Kniphofia pumila and K. thomsonii are widespread from West Africa to Eastern and Central Africa. In this study the genetic diversity and the relationships between five endemic and one widespread Kniphofia species in Ethiopia was conducted based on isoenzymes systems. The electrophoretic analyses of four enzymes systems in the species from ten experimental sites in ten locations revealed seven putative loci, of which PGM-1, PGM-2, AAT-2 and GPI-2 were polymorphic. The species have displayed higher genetic diversity parameters than other endemic plants. The over all mean inbreeding coefficient $(F)$ was positive indicating slight deficiency in the number of heterozygotes. The total genetic diversity varies from 0.5 in K. schimperi to 1.11 in K. isoetifolia indicating very low diversification between the populations with in a species. At the generic level $\mathrm{H}_{\mathrm{T}}$ ranges from 0.034 to 0.470 with a mean of 0.247 . The genetic variation among the species (GST) is $6.6 \%$. Over all mean of genetic distance (0.011) and genetic similarity (0.938) indicated high similarity among the populations. Despite morphological variation particularly in floral morphology and inflorescence architecture, the over all mean of unbiased genetic identity of the species (0.989) is much higher than described for congeneric species $(\mathrm{I}=0.64)$. The results, therefore, indicate that the Ethiopian Kniphofia species share a fairly recent common ancestor, but have differentiated in floral and inflorescence character through rapid evolution. This hypothesis needs, however, further testing.
\end{abstract}

Key words/phrases: Endemism, genetic diversity, isoenzyme, kniphofia, inbreeding coefficient

\section{INTRODUCTION}

The genus Kniphofia Moench belongs to the family Asphodelaceae. Codd (1968) indicated that the genus Kniphofia is represented by 70 species. Fortyfive species occur in South Africa. One species occurs in Arab Republic of Yemen, 2 in Malagasy Republic, and 23 in Tropical Africa. Sebsebe Demissew and Nordal (1997) recognized seven species of genus Kniphofia in the Ethiopian flora. They are Kniphofia foliosa Hochst., K. hildebrandtii Cufod., K. insignis Rendle, K. isoetifolia Hochst., K. pumila (AIT.) Kunth, K. schimperi Baker and K. thomsonii Baker. K. foliosa, K. hildebrandtii, K. insignis, K. isoetifolia, and K. schimperi are endemic to Ethiopia. Kniphofia pumila and K. thomsonii is widespread (widely distributed) from West Africa to Eastern and Central Africa (Marais, 1973).

The genus Kniphofia is useful in the field of Horticulture and is grown in home and botanical gardens, and naturally occurring species of
Kniphofia are important as honeybee-plants for pollen source and nectar (Fichtl and Admassu Adi, 1994). The secondary metabolites from genus Kniphofia such as knipholone and related natural phenylanthraquinones, are considered to be a new group of potential antimalarials and anthraquinone aloe-emodin is known to exhibit antileukemic properties (Ermias Dagne and Steglich, 1984; Esayas Berhanu et al., 1986; Bringmann et al., 1999). Also, the roots of Kniphofia foliosa are used in traditional Ethiopian medicine for treatment of abdominal cramps.

These are distributed between $6^{\circ} 00^{\prime} \mathrm{N}$ to $14^{\circ} 00^{\prime}$ $\mathrm{N}$ latitude and $33^{\circ} 00^{\prime} \mathrm{E}$ to $41^{\circ} 46^{\prime} \mathrm{E}$ longitude that falls within the mountainous area of the country with disjunctive distribution. K. foliosa, K. isoetifolia and $K$. schimperi, unlike $K$. insignis and $K$. hildebrandtii, are not geographically restricted to the central highlands. Their habitat varies from montane grassland (characterised by Olea europaea subsp. cuspidata, Juniperus procera, Celtis africana, 
Euphorbia ampliphylla, Carissa edulis, Rosa abyssinica, Mimusops kummel and Ekebergia capensis), to subalpine Erica arborea zone (characterized by Erica arborea, Lobelia cynchopetalum and species of grasses mainly of Festuca, Poa and Agrostis).

The objective is to study the genetic variation and relation among and within species and populations. Previously no such studies have been conducted although the basic taxonomy has been studied as part of the Ethiopian Flora Project. The results may assist future conservation plan of the species.

\section{MATERIALS AND METHODS}

\section{Biological material}

The following species were included in the isoenzyme analysis: Kniphofia foliosa, $K$. hildebrandtii, K. insignis, K. isoetifolia, K. schimperi and K. pumila. The plants were grown in a greenhouse at the University of Oslo from seeds randomly collected from the experimental plots in ten localities in Ethiopia (Table 1 and Fig. 1). The seeds from the individual genet and as well from individual mother plant were collected separately and grown in separate pots. From each population 30 to 90 individuals were analysed. The voucher specimens of the analyzed Kniphofia species are kept in National Herbarium of the Addis Ababa University.

\section{Electrophoretic analysis}

The isoenzymes analysis procedure was modified from that of Wendel and Weeden (1990) that wicks are not removed from the gels, but resolution is generally of equivalent quality. The starch used for the preparation of the gel was Sigma S-4501. The buffer systems, electrode and gel buffers, were categorized as D-system and AB-systems. The Dsystem was with modification of Stuber et al. (1977) that the $\mathrm{pH}$ of the electrode and gel buffers is 6.5. The gel buffer is prepared by adding $125 \mathrm{ml}$ of electrode buffer to 375 distilled water (1:3). ABsystem was with modification of Ashton and Braden (1961) that the gel buffer is prepared by diluting $50 \mathrm{ml}$ of electrode buffer $(11.87 \mathrm{~g} / 1$ Boric acid and $1.6 \mathrm{~g} / 1$ Lithium Hydroxide) in $450 \mathrm{ml}$ of Tris-citrate $(6.05 \mathrm{~g} / 1$ Tris- $0.31 \mathrm{~g} / 1$ citric acid). The Dsystem gels were stained for glucose-6-phosphate dehydrogenase (G6PDH 1.1.1.49) and phosphoglucomutase (PGM 5.4.2.2). The AB-system gels were stained for aspartate amino transferase (AAT 2.6.1.1) and glucose-6-phosphate isomerase (GPI 5.3.1.9). Relative mobility (Rf) was calculated based on the migration of a band relative to the front. The alleles at a locus were designated by alphabets. The fastest and the anodal was denoted as ' $\mathrm{A}$ ' allele and the rest were assigned according to decreasing order of electrophoretic mobility in ascending order of the alphabets.

Table 1. The location of seed collection sites in Ethiopia (voucher number represents the populations).

\begin{tabular}{|c|c|c|c|c|c|}
\hline $\begin{array}{l}\text { Scientific } \\
\text { name }\end{array}$ & Pop. No. & Region and Locality & Lat. and Long. & $\begin{array}{l}\text { Altitude } \\
\text { (m.a.s.l.) }\end{array}$ & Description of habitat \\
\hline \multirow[t]{2}{*}{ K. foliosa } & fol-10 & Bale: Dinsho & $7^{\circ} 06^{\prime} \mathrm{N}, 39^{\circ} 48 \mathrm{E}$ & 3500 & $\begin{array}{l}\text { Montane forest and grassland Dominant plant } \\
\text { Juniperus procera \& Hagenia abyssinica. }\end{array}$ \\
\hline & fol-13 & N. Shewa: Ali Doro & $7^{\circ} 04^{\prime} \mathrm{N}, 39^{\circ} 47^{\prime} \mathrm{E}$ & 3200 & $\begin{array}{l}\text { Erica arborea zone. Red clay soil with rocky out } \\
\text { cropping and surrounded by farmlands. }\end{array}$ \\
\hline K. hildebrandtii & hild-4 & W. Shewa: Gheddo & $9^{\circ} 01^{\prime} \mathrm{N}, 37^{\circ} 30^{\prime} \mathrm{E}$ & 2450 & $\begin{array}{l}\text { Over grazed grassland. With newly planted } \\
\text { Eucalyptus trees. On top of mountain. }\end{array}$ \\
\hline \multirow[t]{2}{*}{ K. insignis } & ins-8 & N. Shewa: Torban Ashie & $9^{\circ} 20^{\prime} \mathrm{N}, 37^{\circ} 12^{\prime} \mathrm{E}$ & 2800 & $\begin{array}{l}\text { Meadow waterlogged in the rainy season. } \\
\text { Surrounded by farmlands. }\end{array}$ \\
\hline & ins-12 & E. Shewa: Bull Workie & $9^{\circ} 19^{\prime} \mathrm{N}, 39^{\circ} 32^{\prime} \mathrm{E}$ & 2750 & $\begin{array}{l}\text { Meadow waterlogged in the rainy season. } \\
\text { Grazing land for sheep enterprise. }\end{array}$ \\
\hline \multirow[t]{2}{*}{ K. isoetifolia } & iso-1 & Bale: Dinsho & $7^{\circ} 08^{\prime} \mathrm{N}, 39^{\circ} 48^{\prime} \mathrm{E}$ & 3000 & Marshy montane grassland. \\
\hline & iso-2 & Arussie: Bekojji & $7^{\circ} 15^{\prime} \mathrm{N}, 38^{\circ} 53^{\prime} \mathrm{E}$ & 2600 & $\begin{array}{l}\text { Marshy grassland beside a spring. surrounded } \\
\text { by farmlands. }\end{array}$ \\
\hline K.pumila & pum-6 & Sidamo: Yirba Muda & $6^{\circ} 15^{\prime} \mathrm{N}, 38^{\circ} 42^{\prime} \mathrm{E}$ & 2700 & Red soil. Disturbed part of montane forest. \\
\hline \multirow[t]{2}{*}{ K. schimperi } & sch-5 & W. Shewa: Goro Wonchi & $9^{\circ} 46^{\prime} \mathrm{N}, 38^{\circ} 31^{\prime} \mathrm{E}$ & 3100 & $\begin{array}{l}\text { Erica arborea zone. Eucalyptus trees and } \\
\text { scattered Juniperus procera. }\end{array}$ \\
\hline & sch-14 & Addis Ababa: Entoto & $9^{\circ} 47^{\prime} \mathrm{N}, 38^{\circ} 43^{\prime} \mathrm{E}$ & 2820 & $\begin{array}{l}\text { Erica arboria Zone. With scattered Hagenia } \\
\text { abyssinica and Juniperus procera. }\end{array}$ \\
\hline
\end{tabular}




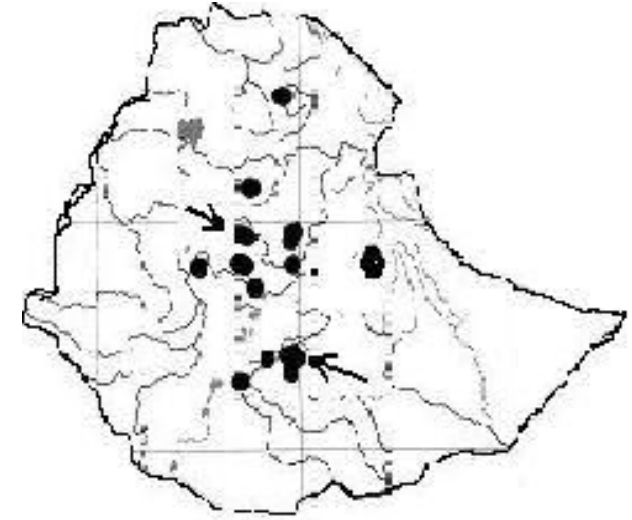

K. foliosa: Upper left Ali Doro and lower right Dinsho

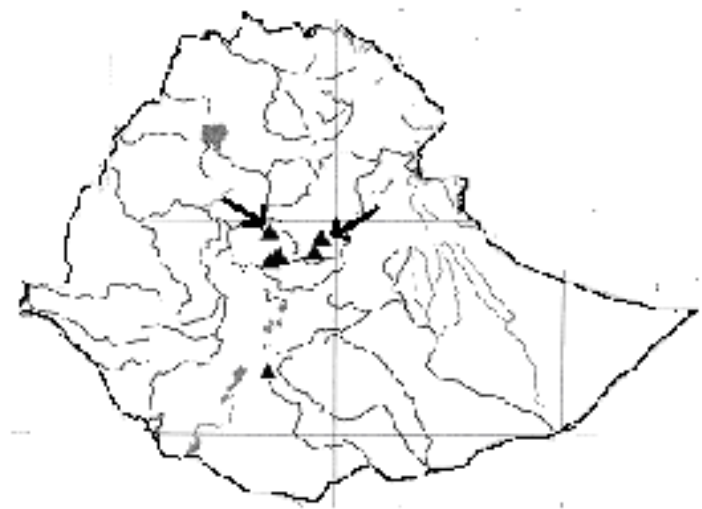

K.insignis: upper left Torban Ashie and right Bull Workie

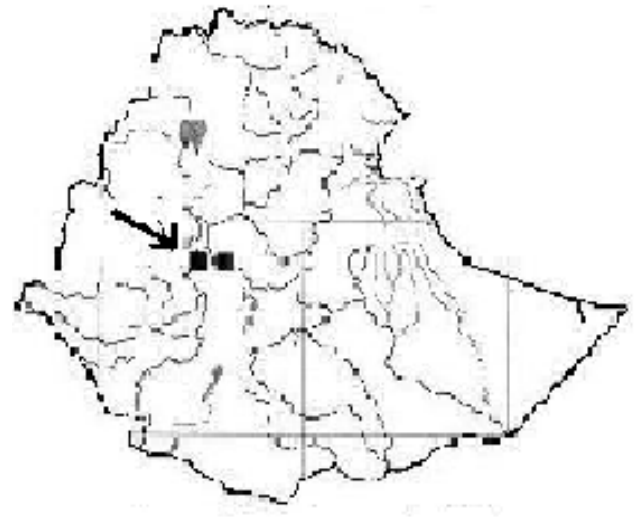

K. hildebrandtti: Gheddo

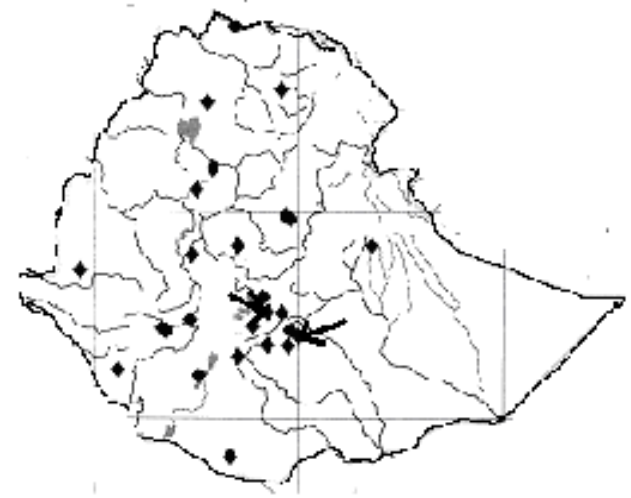

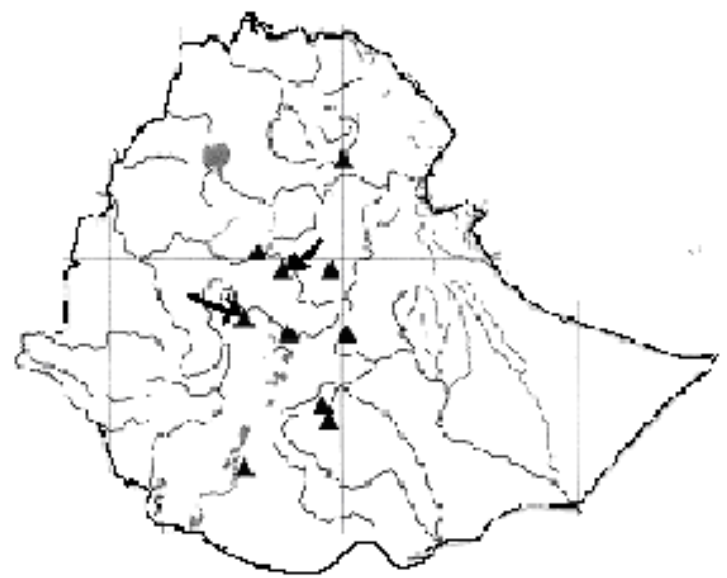

K. schimperi: lower left: Goro Wonchi and upper right Entoto

Fig. 1 The distribution of endemic Kniphofia species in Ethiopia. The arrows indicate the experimental sites. The data to determine the distribution of Kniphofia species were collected from the National Herbarium of Addis Ababa University (ETH), Royal Botanical Garden; Kew (K), and of the Natural History Museum of London (BM). 


\section{Data analysis}

The basic genetic parameters, Hardy-Weinberg test, and F-statistics, genetic distance, identity and similarity analysis were calculated, and dendrogram was generated based on a UPGMA analysis (Sokal and Michener, 1958) using BIOSYS-1 release 7.1 (Swofford and Selander, 1989) and POPGENE version 3.1 (Francis and Rong-Cai, 1999) computer programs. BIOSYS-1 release 7.1 and POPGENE version 1.30 are useful in population genetics and related fields. Their major features are for analysis of basic genetic parameters, Hardy-Weinberg test, F-statistics, Nei's genetic distances and identities (Nei, 1978), and genetic similarity (Rogers, 1972) between groups or populations. Besides, POPGENE enables to estimate Shannon-Weaver diversity parameters and to generate dendrogram based on a UPGMA analysis (Sokal and Michener, 1958).

\section{RESULTS}

Out of the four enzyme systems analysed only PGM, AAT and GPI were polymorphic and interpretable. PGM has three putative loci (Fig. 2). PGM-1 displayed five alleles (A-E). The alleles A, B and $C$ are common and found in all the species.
Allele D is less common and only found in Kniphofia insignis and K. schimperi. Allele E is a rare allele only found in one population of K. schimperi ("sch-14", Table 1). PGM-2 displayed three alleles (A-C). Allele B is common in all and fixed in half of the populations. Allele A is found in K. insignis and in one population of K. isoetifolia ("iso-1"). Allele C is found in $K$. isoetifolia and in one population of $K$. foliosa ("fol-13") and K. insignis ("ins-8"). PGM-3 is fixed and monomorphic in all the species (Table 2).

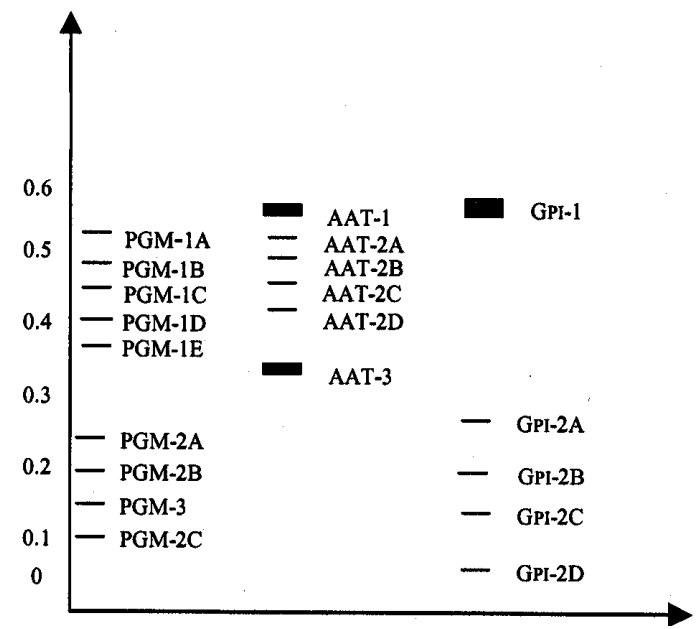

Fig. 2. The relative mobility of the alleles in the variable loci of PGM, AAT and GPI. The shaded bands represent blurred bands.

Table 2. The sample size (N) and mean, standard error (se) of the allele frequencies of polymorphic locus in the populations of genus Kniphofia species.

\begin{tabular}{|c|c|c|c|c|c|c|c|c|c|c|c|c|c|}
\hline \multicolumn{14}{|c|}{ Population of genus Kniphofia species } \\
\hline \multirow{2}{*}{ Locus } & Alleles & fol-10 & fol-13 & hild-4 & ins-8 & ins-12 & iso-1 & iso-2 & sch-5 & sch-14 & pum-6 & \multirow{2}{*}{ mean } & \multirow{2}{*}{ se } \\
\hline & $(\mathrm{N})$ & 39 & 30 & 35 & 31 & 36 & 90 & 36 & 46 & 73 & 51 & & \\
\hline \multirow[t]{5}{*}{ PGM-1 } & A & 0.103 & 0.125 & 0.071 & 0.177 & 0.083 & 0.150 & 0.139 & 0.043 & 0.048 & 0.049 & 0.099 & 0.047 \\
\hline & B & 0.872 & 0.821 & 0.757 & 0.500 & 0.444 & 0.733 & 0.667 & 0.707 & 0.603 & 0.843 & 0.695 & 0.143 \\
\hline & C & 0.026 & 0.054 & 0.171 & 0.258 & 0.417 & 0.117 & 0.194 & 0.217 & 0.281 & 0.108 & 0.184 & 0.117 \\
\hline & $\mathrm{D}$ & 0.000 & 0.000 & 0.000 & 0.065 & 0.056 & 0.000 & 0.000 & 0.033 & 0.062 & 0.000 & 0.022 & 0.029 \\
\hline & $\mathrm{E}$ & 0.000 & 0.000 & 0.000 & 0.000 & 0.000 & 0.000 & 0.000 & 0.000 & 0.007 & 0.000 & 0.001 & 0.002 \\
\hline \multirow[t]{3}{*}{ PGM-2 } & A & 0.000 & 0.000 & 0.000 & 0.016 & 0.042 & 0.011 & 0.000 & 0.000 & 0.000 & 0.000 & 0.007 & 0.004 \\
\hline & B & 1.000 & 0.982 & 1.000 & 0.952 & 0.958 & 0.956 & 0.986 & 1.000 & 1.000 & 1.000 & 0.983 & 0.006 \\
\hline & C & 0.000 & 0.018 & 0.000 & 0.032 & 0.000 & 0.033 & 0.014 & 0.000 & 0.000 & 0.000 & 0.010 & 0.004 \\
\hline \multirow[t]{4}{*}{$A A T-2$} & A & 0.000 & 0.000 & 0.000 & 0.000 & 0.000 & 0.072 & 0.083 & 0.000 & 0.000 & 0.000 & 0.016 & 0.010 \\
\hline & B & 0.949 & 0.946 & 1.000 & 0.968 & 0.931 & 0.911 & 0.889 & 0.837 & 0.842 & 0.980 & 0.925 & 0.018 \\
\hline & C & 0.000 & 0.000 & 0.000 & 0.000 & 0.000 & 0.017 & 0.028 & 0.120 & 0.137 & 0.000 & 0.030 & 0.017 \\
\hline & $\mathrm{D}$ & 0.051 & 0.054 & 0.000 & 0.032 & 0.069 & 0.000 & 0.000 & 0.043 & 0.021 & 0.020 & 0.029 & 0.008 \\
\hline \multirow[t]{4}{*}{ GPI-2 } & A & 0.000 & 0.000 & 0.000 & 0.129 & 0.125 & 0.150 & 0.278 & 0.000 & 0.000 & 0.039 & 0.072 & 0.030 \\
\hline & B & 0.000 & 0.000 & 0.000 & 0.000 & 0.000 & 0.000 & 0.000 & 0.098 & 0.027 & 0.000 & 0.013 & 0.010 \\
\hline & C & 0.962 & 0.911 & 0.757 & 0.677 & 0.694 & 0.850 & 0.722 & 0.750 & 0.760 & 0.961 & 0.804 & 0.034 \\
\hline & D & 0.038 & 0.089 & 0.243 & 0.194 & 0.181 & 0.000 & 0.000 & 0.152 & 0.212 & 0.000 & 0.111 & 0.031 \\
\hline
\end{tabular}


AAT has three putative loci (Fig. 2). The loci identified as AAT- 1 and AAT- 3 are blurred and not interpretable. The middle locus identified as AAT-2 has four alleles (A-D). Allele B is most common in all species and populations. Allele $\mathrm{A}$ is rare and only found in $K$. isoetifolia. Allele $C$ is also rare but found in K. isoetifolia and K. schimperi. Allele D is found in all the species except in K. hildebrandtii and K. isoetifolia (Table 2).

GPI has two putative loci (Fig. 2). The anodal locus has bands without sharp distinction. It is assumed to be of chloroplast origin, and was not further interpreted. The cathodal locus GPI-2 has four alleles (A-D). Allele $C$ is the most common in all the species and populations. Allele $\mathrm{A}$ is found in K. insignis, K. isoetifolia and K. pumila. Allele B is found only in $K$. schimperi. A very faint mark of allele B was observed in K. pumila and more rarely in K. foliosa when the gel was kept in the stain solution for longer period than usual. These bands were regarded as ghosts and were not scored. Allele D is present in all species except in $K$. isoetifolia and K. pumila. A third putative locus was observed towards the cathode from the application point, but was not consistently expressed and accordingly not included in the data or final analysis (Table 2).

G6PDH has two regions identified as G6PDH-1 and G6PDH-2 with Rf values 0.26 and 0.14; respectively. Both were monomorphic in all the samples.
Four loci were polymorphic and they all together displayed 16 allelic bands. At the species level, the percentage of polymorphic loci $(\mathrm{P})$ ranges from $28.6 \%$ in K. hildebrandtii to $57.1 \%$ in K. foliosa, K. insignis and $K$. isoetifolia (Table 3). The lowest mean number of alleles (A) per locus is 1.43 in $K$. hildebrandtii and the highest is 2.14 in $K$. insignis and $K$. schimperi. K. foliosa has the lowest mean number of alleles per polymorphic locus $(\mathrm{AP}=2.25)$, and $K$. schimperi has the highest $(\mathrm{AP}=3.6)$. The mean effective number of alleles per locus (Ae) range from 1.07 in K. pumila and $K$. foliosa to 1.42 in K. insignis (Table 3). The values of these diversity parameters on the population level are in fact of the same order of magnitude as for the species level.

The expected heterozygosity $\left(\mathrm{H}_{\mathrm{e}}\right)$ in the species ranges from 0.056 in K. pumila to 0.188 in $K$. insignis. At the population level, "fol-10" has the lowest and "ins-8" the highest value (Table 3 ).

Out of the 48 individual loci tested for deviation from Hardy-Weinberg equilibrium, six (12.5\%) indicated significant difference $(p<0.05)$ and found scattered in five populations. At the population level the mean of the inbreeding coefficient $(F)$ is positive indicating a slight deficiency in heterozygosity though at individual locus level PGM-1 in "sch-14", AAT-2 in "ins-12" and "iso-1", and GPI-2 in "fol-13", "sch-5" and "sch-14" are negative indicating slight excess in heterozygosity (Table 4).

Table 3. Estimate of genetic variability within each population and species of genus Kniphofia.

\begin{tabular}{lcccccc}
\hline Population & $P^{*}$ & $A$ & $A P$ & $A_{\mathrm{e}}$ & $H_{\mathrm{o}} \pm \mathrm{se}$ & $H_{\mathrm{e}} \pm \mathrm{se}$ \\
\hline fol-10 & 42.86 & 1.57 & 2.33 & 1.07 & $0.059 \pm 0.033$ & $0.058 \pm 0.033$ \\
fol-13 & 57.14 & 1.71 & 2.25 & 1.11 & $0.082 \pm 0.044$ & $0.088 \pm 0.044$ \\
K. foliosa & 57.14 & 1.71 & 2.25 & 1.09 & $0.068 \pm 0.037$ & $0.070 \pm 0.037$ \\
hild-4 & 28.60 & 1.43 & 2.50 & 1.18 & $0.106 \pm 0.110$ & $0.110 \pm 0.071$ \\
ins-8 & 57.14 & 2.14 & 3.00 & 1.42 & $0.194 \pm 0.107$ & $0.187 \pm 0.103$ \\
ins-12 & 57.14 & 2.00 & 3.00 & 1.39 & $0.171 \pm 0.090$ & $0.188 \pm 0.097$ \\
K. insignis & 57.14 & 2.14 & 3.00 & 1.42 & $0.181 \pm 0.097$ & $0.188 \pm 0.100$ \\
iso-1 & 57.14 & 2.00 & 2.50 & 1.20 & $0.121 \pm 0.056$ \\
iso-2 & 57.14 & 1.86 & 2.50 & 1.28 & $0.151 \pm 0.072$ & $0.134 \pm 0.061$ \\
K. isoetifolia & 57.14 & 2.00 & 2.75 & 1.22 & $0.129 \pm 0.059$ & $0.164 \pm 0.081$ \\
sch-5 & 42.86 & 2.00 & 3.30 & 1.27 & $0.146 \pm 0.071$ & $0.164 \pm 0.080$ \\
sch-14 & 42.86 & 2.14 & 3.60 & 1.32 & $0.141 \pm 0.077$ \\
K. schimperi & 42.86 & 2.14 & 3.60 & 1.30 & $0.143 \pm 0.074$ & $0.172 \pm 0.087$ \\
pum-6 & 42.86 & 1.57 & 2.33 & 1.07 & $0.053 \pm 0.035$
\end{tabular}

$P^{*}$ is percentage of polymorphic loci at $95 \%$ criterion; $A$ is the mean number of alleles per locus; $A P$ is the mean number of alleles per polymorphic locus, $A_{\mathrm{e}}$ is the effective number of alleles per locus; $H_{\mathrm{o}}$ is the observed heterozygosity; $H_{\mathrm{e}}$ is unbiased estimate of the heterozygosity expected under Hardy-Weinberg equilibrium; and se is standard error. 
Table 4. Chi-square test for the deviation of the observed and expected allele frequencies from HardyWeinberg equilibrium at the polymorphic loci.

\begin{tabular}{|c|c|c|c|c|c|c|c|c|c|c|c|c|}
\hline \multirow{2}{*}{ Pop. } & \multicolumn{3}{|c|}{ PGM-1 } & \multicolumn{3}{|c|}{ PGM-2 } & \multicolumn{3}{|c|}{ AAT-2 } & \multicolumn{3}{|c|}{ GPI-2 } \\
\hline & $\chi^{2}$ & $\mathrm{df}$ & $\mathrm{p}$ & $\chi^{2}$ & df & $\mathrm{p}$ & $\chi^{2}$ & $\mathrm{df}$ & $\mathrm{p}$ & $\chi^{2}$ & $\mathrm{df}$ & $\mathrm{p}$ \\
\hline fol-10 & 3.736 & 3 & 0.291 & - & - & - & 0.084 & 1 & 0.771 & 0.041 & 1 & 0.839 \\
\hline fol-13 & 1.546 & 3 & 0.672 & 0.000 & 1 & 1.000 & 0.059 & 1 & 0.808 & 4.288 & 1 & 0.038 * \\
\hline hild-4 & 6.906 & 3 & 0.075 & - & - & - & - & - & - & 0.814 & 1 & 0.367 \\
\hline ins-8 & 7.495 & 6 & 0.278 & 0.053 & 3 & 0.997 & 0.017 & 1 & 0.896 & 2.715 & 3 & 0.438 \\
\hline ins-12 & 9.765 & 6 & 0.135 & 0.045 & 1 & 0.832 & 5.890 & 1 & $0.015^{* *}$ & 3.948 & 3 & 0.267 \\
\hline iso-1 & 1.528 & 3 & 0.676 & 0.169 & 3 & 0.982 & 17.221 & 3 & $0.001^{* *}$ & 0.754 & 1 & 0.385 \\
\hline iso-2 & 4.386 & 3 & 0.223 & 0.000 & 1 & 1.000 & 0.486 & 3 & 0.922 & 0.073 & 1 & 0.786 \\
\hline sch-5 & 12.196 & 6 & 0.058 & - & - & - & 1.126 & 3 & 0.771 & 13.538 & 3 & $0.004^{*}$ \\
\hline sch-14 & 37.331 & 10 & $0.000^{* *}$ & - & - & - & 1.589 & 3 & 0.662 & 23.229 & 3 & $0.000^{* *}$ \\
\hline pum-6 & 1.094 & 3 & 0.779 & - & - & - & 0.010 & 1 & 0.920 & 0.063 & 1 & 0.802 \\
\hline
\end{tabular}

${ }^{*} \mathrm{p}<0.05 ;{ }^{* *} \mathrm{p}<0.005$ significant different between observed and expected allelic frequency.

The total genetic diversity at the polymorphic loci $\left(\mathrm{H}_{\mathrm{T}}\right)$ in the species ranges from 0.123 in $K$. foliosa to 0.396 in K. schimperi. The proportion of $\mathrm{H}_{\mathrm{T}}$ harboured within the population in K. foliosa, $K$. insignis, K. isoetifolia, and K. schimperi ranges from $99.5 \%$ in $K$. schimperi to $98.9 \%$ in K. isoetifolia indicating very low diversification between the populations (Table 5). At the generic level $\mathrm{H}_{\mathrm{T}}$ ranges from 0.034 to 0.470 with a mean of 0.247 . The genetic variation among the species $\left(\mathrm{G}_{\mathrm{ST}}\right)$ is $6.6 \%$ (Table 6).

Table 5. Estimate of the F-statistics and unbiased Nei's genetic diversity statistics (1978) for the polymorphic loci.

\begin{tabular}{|c|c|c|c|c|c|c|c|}
\hline Species & Locus & $F_{\text {IS }}$ & $F_{\mathrm{IT}}$ & $H_{\mathrm{T}}$ & $H_{\mathrm{S}}$ & $D_{\mathrm{ST}}$ & $G_{\text {ST }}$ \\
\hline \multirow{3}{*}{ K. foliosa } & PGM-2 & -0.018 & -0.009 & 0.015 & 0.015 & 0.000 & 0.009 \\
\hline & GPI-2 & 0.222 & 0.230 & 0.113 & 0.112 & 0.001 & 0.011 \\
\hline & Mean & 0.022 & 0.027 & 0.123 & 0.122 & 0.001 & 0.006 \\
\hline \multirow{2}{*}{ K. hildebrandtii } & GPI-2 & -0.165 & ------ & 0.373 & ------ & ------ & ------ \\
\hline & Mean & 0.023 & ----- & 0.386 & ------ & ----- & ------ \\
\hline \multirow[t]{3}{*}{ K. insignis } & PGM-1 & 0.092 & 0.106 & 0.646 & 0.637 & 0.009 & 0.015 \\
\hline & PGM-2 & -0.041 & -0.036 & 0.087 & 0.087 & 0.000 & 0.005 \\
\hline & AAT-2 & 0.229 & 0.234 & 0.100 & 0.099 & 0.001 & 0.007 \\
\hline \multirow{4}{*}{ K. isoetifolia } & PGM-2 & -0.032 & -0.025 & 0.070 & 0.070 & 0.000 & 0.006 \\
\hline & $A A T-2$ & 0.030 & 0.031 & 0.176 & 0.176 & 0.000 & 0.001 \\
\hline & GPI-2 & 0.052 & 0.075 & 0.305 & 0.298 & 0.007 & 0.024 \\
\hline & Mean & 0.078 & 0.088 & 0.250 & 0.248 & 0.003 & 0.011 \\
\hline \multirow[t]{4}{*}{ K. schimperi } & PGM-1 & 0.033 & 0.041 & 0.519 & 0.514 & 0.004 & 0.008 \\
\hline & $A A T-2$ & 0.085 & 0.085 & 0.277 & 0.277 & 0.000 & 0.001 \\
\hline & GPI-2 & 0.319 & 0.323 & 0.391 & 0.389 & 0.002 & 0.006 \\
\hline & Mean & 0.141 & 0.146 & 0.396 & 0.393 & 0.002 & 0.005 \\
\hline K. pumila & PGM-1 & 0.073 & ---- & 0.278 & ------ & ----- & ------ \\
\hline
\end{tabular}


Table 6. Estimate of the F-statistics and unbiased Nei's genetic diversity statistics (1978) for the polymorphic loci at generic level.

\begin{tabular}{lclllll}
\hline Locus & \multicolumn{1}{l}{$F_{\mathrm{IS}}$} & $F_{\mathrm{IT}}$ & $H_{\mathrm{T}}$ & $H_{\mathrm{S}}$ & $D_{\mathrm{ST}}$ & $G_{\mathrm{ST}}$ \\
\hline PGM-1 & 0.094 & 0.154 & 0.470 & 0.440 & 0.030 & 0.064 \\
PGM-2 & -0.031 & 0.011 & 0.034 & 0.033 & 0.001 & 0.020 \\
AAT-2 & 0.085 & 0.133 & 0.158 & 0.150 & 0.008 & 0.052 \\
GPI-2 & 0.036 & 0.113 & 0.327 & 0.301 & 0.026 & 0.080 \\
Mean & 0.069 & 0.131 & 0.247 & 0.221 & 0.016 & 0.066 \\
\hline
\end{tabular}

The similarity among the populations is higher than among the species as shown by Rogers (1972) similarity and unbiased Nei's (1978) genetic distance (Table 7). The similarity between the population ranges from 0.965 to 0.984 with a mean of 0.973 . The lowest similarity is between populations of $K$. isoetifolia and the highest is between populations of $K$. foliosa. The largest genetic distance is between "fol-10" and "ins-12" (0.034, Table 7) with a mean of 0.011 that indicated very high genetic identity between the populations. Pair wise comparison of the species was made by pooling all genotypes to a species level and the species similarity coefficient ranges from 0.909 to 0.956 with mean of 0.939 and genetic distance ranges from 0.001 to 0.027 with mean 0.011 . The smallest value is between $K$. foliosa and K. pumila and the highest value is between the $K$. isoetifolia and K. schimperi.

The phenogram of the unweighted pair group method with arithmetic average (UPGMA) clustering showed two major groups that depicted the relation among the species. The first grouping includes K. foliosa, K. pumila and K. isoetifolia. The second includes K. hildebrandtii, K. schimperi and K. insignis (Fig. 3). K. insignis appeared more divergent in the cluster than the rest.

Table 7. Rogers (1972) genetic similarity (above the diagonal), and Nei's (1978) unbiased genetic distance (below the diagonal) and mean of genetic identities ( $I^{*}$ values): paired identities between each population and other populations.

\begin{tabular}{lrrrrrrrrrrr}
\hline pop. & fol-10 & \multicolumn{1}{c}{ fol-13 } & hild-4 & \multicolumn{1}{l}{ ins-8 } & ins-12 & iso-1 & iso-2 & sch-5 & sch-14 & pum-6 & $I^{*}$ \\
\hline fol-10 & ----- & 0.984 & 0.940 & 0.911 & 0.900 & 0.948 & 0.922 & 0.931 & 0.917 & 0.980 & 0.987 \\
fol-13 & 0.000 & ----- & 0.950 & 0.925 & 0.912 & 0.957 & 0.931 & 0.939 & 0.927 & 0.972 & 0.991 \\
hild-4 & 0.009 & 0.005 & ----- & 0.943 & 0.928 & 0.942 & 0.935 & 0.957 & 0.954 & 0.954 & 0.992 \\
ins-8 & 0.023 & 0.017 & 0.008 & ---- & 0.969 & 0.935 & 0.939 & 0.932 & 0.942 & 0.916 & 0.988 \\
ins-12 & 0.034 & 0.027 & 0.014 & 0.002 & ----- & 0.918 & 0.926 & 0.928 & 0.941 & 0.902 & 0.983 \\
iso-1 & 0.005 & 0.004 & 0.009 & 0.012 & $0.020----$ & 0.965 & 0.938 & 0.926 & 0.953 & 0.991 \\
iso-2 & 0.015 & 0.013 & 0.013 & 0.008 & 0.014 & 0.003 & ----- & 0.939 & 0.932 & 0.929 & 0.989 \\
sch-5 & 0.011 & 0.008 & 0.004 & 0.010 & 0.013 & 0.009 & $0.011----$ & & 0.975 & 0.935 & 0.992 \\
sch-14 & 0.018 & 0.013 & 0.006 & 0.007 & 0.008 & 0.013 & 0.014 & 0.001 & ----- & 0.92 & 0.990 \\
pum-6 & 0.001 & 0.001 & 0.008 & 0.020 & 0.028 & 0.004 & 0.012 & 0.009 & 0.015 & ----- & 0.989 \\
\hline
\end{tabular}

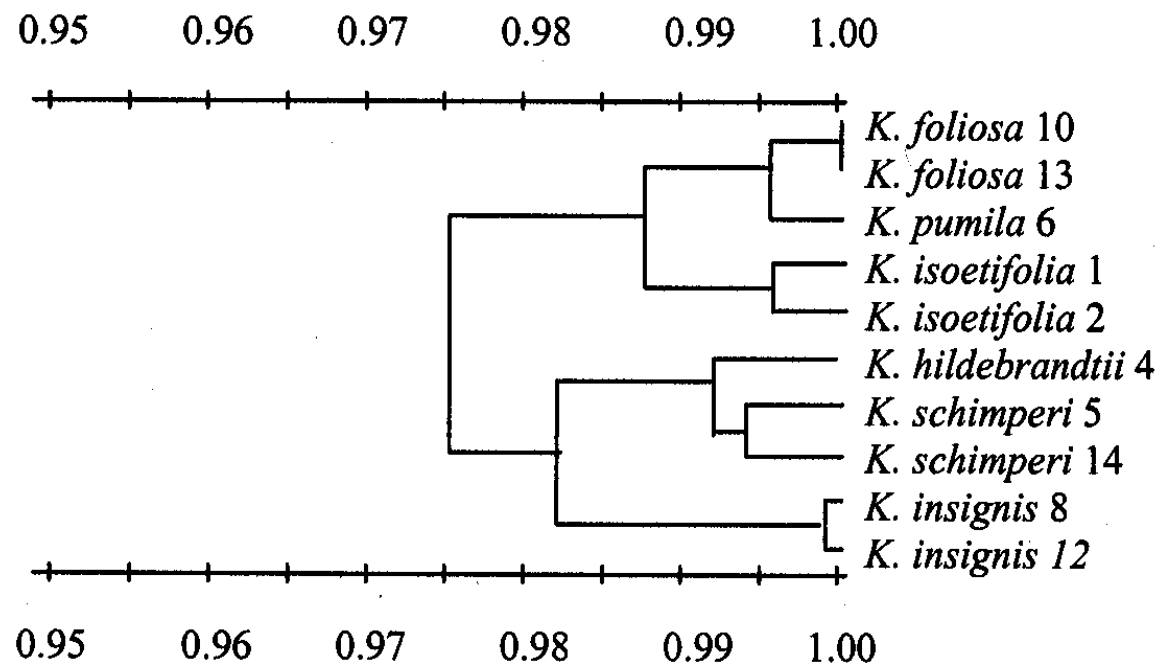

Fig. 3. Phenogram expressing overall level of genetic similarity among Kniphofia species based on Roger's (1972) coefficient of genetic similarity. 


\section{DISCUSSION}

\section{Variation within the populations}

Four common parameters for the comparisons of intrapopulational variation are presented by Hamrick and Godt (1989), percentage of polymorphic loci $(\mathrm{P})$, number of alleles per locus (A), effective number of alleles per locus $\left(\mathrm{A}_{\mathrm{e}}\right)$, and expected heterozygosity $\left(\mathrm{H}_{\mathrm{e}}\right)$. The mean value of $\mathrm{P}$ for plants (from data which were published until 1989) was calculated to be $34.2 \%$. The analysed populations of genus Kniphofia all show a higher percentage of polymorphic loci, but here, it should be remarked that the number of loci and population is low, so the result may be biased. The indicated average value for A is 1.53. In our study all the populations scored higher in this parameter (from 1.57 to 2.14). When it comes to effective number of alleles, the average recorded by Hamrick and Godt (1989) is 1.15, and the populations of K. insignis, K. schimperi, and $K$. isoetifolia have a higher value. K. hildebrandtii scores close to the average, and the populations of $K$. foliosa and K. pumila scores below the average. The same relations are revealed by the expected heterozygosity (average for plants: 0.113), where again the populations of $K$. insignis showed the highest diversity $\left(\mathrm{H}_{\mathrm{e}}=0.187-0.188\right)$, and $\mathrm{K}$. pumila and $K$. foliosa the lowest $\left(\mathrm{H}_{\mathrm{e}}=0.056-0.058\right)$ diversity. It is striking that the only non-endemic species, K. pumila displayed the lowest diversity, but it should be remarked that only one population of this species was included in the analyses.

The endemic taxa, with an exception of K. foliosa, displayed more variation than expected, which indicates that they are not depleted of genetic variation at the population level. In the survey of Hamrick and Godt (1989) the expected heterozygosity that is particularly calculated for long-lived herbaceaous perennial taxa is $\mathrm{H}_{e}=0.084$ and for endemic taxa is $\mathrm{H}_{\mathrm{e}}=0.063$, both attributes fitting to the endemic Kniphofia taxa.

The populations were mainly in HardyWeinberg equilibrium, and the few exceptions found were scattered both at locus and population. The outcrossing, probably by birds in most of the species, is accordingly rather efficient. The few significant deviations found showed a slight deficiency in the number of expected heterozygotes, which might indicate a slight inbreeding. The taxa might have a certain clonal vegetative growth leading to neighbours of the same genetic make up. This may further lead to consanguineous mating or Wahlund effect (Turner et al., 1982; Harada and Iwasa, 1996).

\section{Variation among the populations}

It was only possible to obtain material for more than one population for four of the species (Kniphofia foliosa, K. insignis, K. isoetifolia and K. Schimperi). In all cases the amount of variation that could be ascribed to the among population component was extremely low. It varied from $0.5 \%$ in K. schimperi to $1.1 \%$ in K. isoetifolia. Hamrick et al. (1991) have, in comparison, found that the average amount of variation among population in outcrossing plant species is about $10 \%$. The same pattern is found when the genetic identities are compared. They show very high values ranging from 0.965 to 0.984 and the genetic distances are correspondingly low. As a whole the high genetic identity found between populations of all the species is predominantly the consequence of the distribution of the more common alleles and few rare alleles (Brown, 1990).

The most straightforward explanation for the low among population variation is gene flow. The conspecific populations are, however, situated with a far distance between them. Seed dispersal does not seem very probable under the conditions we found in the region today, and gene flow via pollen seems improbable given the disjunctive distribution. Even if we do no know the behaviour and flying distance between flower visits for the pollinators, the distance also in this respect appear to be a little too much.

The populations might represent fragments of a more continuous distribution in earlier times. In this case our result indicates that this fragmentation has taken place recently and that there has not been enough time to accumulate different alleles by mutation. Otherwise the populations are expected to lead to genetic drift and increased level of genetic divergence as the population size become smaller and gene flow decreases (Crawford, 1983).

\section{Relation between the species}

The analysed species show a strong genetic similarity, as shown by all the different analyses. 
The amount of variation found among the species $\left(\mathrm{G}_{\mathrm{ST}}=6.6\right)$ is in fact lower than the expectation for among intraspecific populations of outcrossing species $(=10 \%)$. This pattern is further supported by the values for the genetic identities among nonspecific populations (ranging from $\mathrm{I}=0.90$ to 0.98 ) and higher than the value of the genetic identify among congeneric species ( $\mathrm{I}=0.67)$ indicated in Crawford (1983).

When the taxa were clustered according to their genetic similarity, K. foliosa and K. pumila came closest. They are both characterised by very dense racemes and conspicuously exerted stamens. So this grouping is partially supported by the morphology of the taxa. K. isoetifolia clusters next to this pair. The latter share the special sequence of flower opening (from top to bottom) with $K$. pumila. Another species pair is constituted by $K$. hildebrandtii and K. schimperi, species that do not have very close morphological identity. The most deviating species, as depicted by the isoenzymes analysis is K. insignis. Morphologically it is the most deviating by its white flower colour (Sebsebe Demissew and Nordal, 1997).

The six studied species have resemblance in all vegetative characters and in fruits and seeds. They are predominately separated by traits, in the flower morphology and the inflorescence architecture, both particularly connected to pollination. The strange phenomenon of different species, in genetic respect more behaving as conspecific populations, indicates rather recent speciation (McClenaghan and Beauchmap, 1986). The results, therefore, indicate that all the Ethiopian Kniphofia species share a fairly recent common ancestor, but have differentiated in floral and inflorescence character through rapid evolution due to selection by differential pollinator preferences. This hypothesis needs, however, further testing.

\section{ACKNOWLEDGEMENTS}

The authors thank the Ethiopian Petaloid Monocots project (NUFU-Ethiopia) for the financial grant, and Addis Ababa University and University of Oslo for providing the necessary facilities for accomplishment of the study.
REFERENCES

1. Ashton, G.C. and Braden, A.W.H. (1961). Serum $\beta$ globulin polymorphism in mice. Austral. J. Biol. Sci. 14:248-254.

2. Bringmann, G., Menche, D., Mengesh Bezabih, Berhanu Abegaz Molla and Kaminsky, R. (1999). Antiplasmodial activity of knipholone and related natural phenylanthraquinones. Planta Medica 65:757-758.

3. Brown, A.H.D. (1990). The roles of Isoenzyme studies in Molecular Systematics. Aust. Syst. Bot. 3:3946.

4. Codd, L.E. (1968). The South Africa species Kniphofia. Bothalia 9:363-513.

5. Crawford, D.J. (1983). Phylogenetic and Systematic Inferences from Electrophoretic Studies. In: Isozymes in Plant Genetics and Breeding, Part A, pp. 257-287, (Tanksley, S.D. and Orton, T.J., eds). Elsevier, Amsterdam.

6. Ermias Dagne and Steglich, W. (1984). Knipholone: A unique anthraquinone derivative from Kniphofia foliosa. Phytochemistry 23:1729-1732.

7. Esayas Berhanu, Masresha Fetene and Ermias Dagne (1986). Anthraquinones as taxonomic markers in Ethiopian Kniphofia spp. Phytochemistry 25:847-850.

8. Fichtl, R. and Admassu Adi (1994). Honeybee Flora of Ethiopia. DED, Addis Ababa.

9. Francis, C.Y. and Rong-Cai, Y. (1999). POPGENE. Microsoft Window-based Computer Program for Population Genetic Analysis. Version 13.1. University of Alberta, Edmonton, Canada.

10. Hamrick, J.L. and Godt, M.J.W. (1989). Allozyme Diversity in Plant Species. In: Plant Population Genetics, Breeding and Genetic Resources, pp. 4364, (Brown, A.H.D., Clegg, M.T., Kahler, A.L. and Weir, B.S., eds). Sinauer Associates, Sunderland.

11. Hamrick, J.L., Godt, D.A., Murawski, D.A. and Loveless, M.D. (1991). Correlations between species traits and allozyme diversity: implication for conservation. In: Genetic and Conservation of Rare Plants, pp. 77-86, (Falk, D.A. and Holsinge, K.E., eds). Oxford University Press, New York.

12. Harada, Y. and Iwasa, Y. (1996). Analysis of spatial pattern and population processes of clonal plants. Res. Popul. Ecol. 38:153-164.

13. Marais, W. (1973). A revision of the tropical species of Kniphofia (Liliaceceae). Kew Bulletin 28:465-483.

14. McClenaghan, L.R. and Beauchmap, A.C. (1986). Low genic differentiation among isolated populations of the California fan palm (Washingtonia filifera). Evolution 40:315-322. 
15. Nei, M. (1978). Estimation of average heterozygosity and genetic distance from a small number of individuals. Genetics 89:583-590.

16. Rogers, J.S. (1972). Measurements of Genetic Similarity and Genetic Distance. Studies in Genet. VII. University of Texas Pub. 7213:145153.

17. Sebsebe Demissew and Nordal, I. (1997). Asphodelaceae. In: Flora of Ethiopia and Eritrea: Hydrocharitaceae to Arecaceae, Vol. 6, pp. 106115, (Edwards, S., Sebsebe Demissew and Hedberg, I., eds). EMPDA, Addis Ababa, Ethiopia.

18. Sokal, R.R. and Michener, C.D. (1958). A statistical method for evaluating systematic relationships. Univ. Kansas Sci. Bull. 38:1409-1438.

19. Stuber, C.W., Goodman, M.M. and Johnson, F.M. (1977). Genetic control and racial variation of $\beta$ - glucosidase isozymes in maize (Zea may L.). Biochem. Genet. 15:383-394.

20. Swofford, D.L. and Selander, R.B. (1989). BIOSYS-1. A computer program for the analysis of allelic variation in population genetics and biochemical systematics. Release 1.7. University of Illinois, Urbana, Illinois.

21. Turner, M.E., Stephans, J.C. and Anderson, W.W. (1982). Homozygosity and patch structure in populations as a result of nearest-neighbours pollination. Proc. Natl. Acd. Sci. U.S.A. 79:203207.

22. Wendel, J.F. and Weeden, N.F. (1990). Visualization and interpretation of Plant isozymes. In: Isozymes in Plant Biology, pp. 5-46, (Soltis, D.E. and Soltis, P.S., eds). Chapman and Hall, London. 